\title{
Ruminal degradability and intestinal digestion of eight plant protein supplements used in ruminant diets
}

\author{
N.D. Gerber, I.V. Nsahlai", M.L.K. Bonsi and R.M. Gous \\ School of Agricultural Sciences and Agribusiness, University of Natal, P Bag X01, Scottsville, 3209 \\ "Email: nsahlai@ansi.unp.ac.za
}

\section{Introduction}

Low quality roughage diets are usually supplemented with limiting nutrients in order to alleviate nutritional deficiencies in the rumen and enhance roughage utilization. However, supplementary feeding strategies can be made more effective if the properties of the feed are known and can be related to the nutrient requirements of both the ruminal microbes and the host animal. The extent of microbial degradation of protein supplements in the rumen is an indication of what proportion of the feed protein is available for microbial metabolism, which by difference would determine the undegraded protein that could become available to the host animal after enzymatic digestion. This study determined the degradability (three fistulated Jersey cows) of dry matter (DM) and nitrogen (N) and the apparent digestibility of true protein (in cockerels) of eight plant protein supplements used in ruminant diets in South Africa.

\section{Materials and Methods}

Three ruminally fistulated Jersey cows were fed Coast cross 2 hay (K11) ad libitum. The eight protein supplements (Table 1) were milled through a $2-\mathrm{mm}$ screen using a laboratory mill, thoroughly mixed, weighed ( $c a$. $8 \mathrm{~g})$ into nitrogen-free-polyester bags and incubated in the rumen of cows following the method described by Mehrez \& Ørskov (1977). Each sample was incubated for 3, 6, 12, 24, 36, 48, 72 and 96 hours in each of the three cows. At the end of the incubation, bags were removed and rinsed under tap water, washed in a semi-automatic washing machine (cold water) for five cycles lasting five minutes each. The samples were further dried in an oven at $60^{\circ} \mathrm{C}$ for 48 hours. Three zero-hour bags for each protein supplement were subjected to the washing and drying procedures. The protein supplements were analyzed for DM and N (AOAC, 1990). In addition cockerels were force-fed the eight protein supplements, followed by total faecal collection, to determine the apparent digestibility of true protein. The degradation constants were estimated following the exponential model proposed by Ørskov \& McDonald (1979): $P=a+b\left(1-e^{-c t}\right)$, where $P$ is the disappearance at time $t, a$ is the zero time intercept, $b$ is the slowly degradable fraction and $c$ is the degradation rate. The effective degradability, ED, was estimated thus: ED $(\mathrm{g} / \mathrm{kg})=\mathrm{f}(\mathrm{a})+\mathrm{bc} /(\mathrm{c}+\mathrm{k})$; where $\mathrm{k}$ is the rate of passage of particles through the rumen, $\mathrm{f}(\mathrm{a})=\mathrm{a} * 0.3 /(0.3+\mathrm{kl}) ; 0.3$ is assumed to be the rate of degradation of the solubles, while $\mathrm{kl}$ is the liquid passage rate. Differential rates $(\mathrm{k})$ of $0.03,0.05,0.07$ and $\mathrm{kl}$ of $0.05,0.07,0.10$ were assumed when calculating the effective $\mathrm{N}$ loss for sheep, beef and dairy cattle respectively

Table 1 The crude protein $(\mathrm{CP})$ content and degradation properties of dry matter (DM) and nitrogen

$(\mathrm{N})$ of plant protein supplements incubated in the rumens of Jersey cows

\begin{tabular}{lccccccc}
\hline & \multicolumn{3}{c}{ DM Loss properties } & \multicolumn{2}{c}{ CP } & \multicolumn{3}{c}{ N Loss properties } \\
Source & $a(\mathrm{~g} / \mathrm{kg})$ & $b(\mathrm{~g} / \mathrm{kg})$ & $c(/ \mathrm{h})$ & $(\mathrm{g} / \mathrm{kg} \mathrm{DM})$ & $a(\mathrm{~g} / \mathrm{kg})$ & $b(\mathrm{~g} / \mathrm{kg})$ & $c(/ \mathrm{h})$ \\
\hline Canola & 271 & 630 & 0.0859 & 254.9 & 364 & 576 & 0.1311 \\
Copra & 475 & 452 & 0.0366 & 245.7 & 518 & 435 & 0.0352 \\
Cotton & 525 & 444 & 0.0215 & 394.1 & 774 & 247 & 0.0245 \\
Defatted germ & 558 & 447 & 0.0247 & 132.7 & 614 & 337 & 0.0530 \\
Lucerne & 377 & 426 & 0.0578 & 222.6 & 543 & 440 & 0.0810 \\
Lupins & 625 & 379 & 0.0633 & 376.3 & 937 & 61 & 0.0625 \\
Soya & 554 & 521 & 0.0397 & 497.7 & 554 & 463 & 0.0550 \\
Sunflower & 329 & 500 & 0.0600 & 418.0 & 470 & 527 & 0.0807 \\
& & & & & & & \\
SED & 18.5 & 166 & 0.0211 & & 17.3 & 65 & 0.0043 \\
P level & $* * *$ & $\mathrm{NS}$ & $*$ & & $* * *$ & $* * *$ & $* * *$ \\
\hline \multicolumn{1}{l}{ SED: } & &
\end{tabular}

SED: standard error of the difference; NS: $\mathrm{P}>0.05 ; * \mathrm{P}<0.05 ; * * * \mathrm{P}<0.001$ 


\section{Short paper and poster abstracts: $38^{\text {th }}$ Congress of the South African Society of Animal Science \\ Results and Discussion}

The differences among feeds with respect to soluble $\mathrm{N}$, slowly degradable $\mathrm{N}$ and the degradation rate of $\mathrm{N}$ were significant $(\mathrm{P}<0.001$; Table 2). For instance, lupin-N was $94 \%$ soluble, followed by cottonseed and defatted germ (with $77 \& 61 \% \mathrm{~N}$ solubility respectively) while only $36.4 \%$ of canola-N was soluble. Supplements with moderate $\mathrm{N}$ solubility were sunflower, copra, lucerne and soya. The slowly degradable fraction followed the reverse order. The rates of $\mathrm{N}$ degradation were highest for canola, lucerne and sunflower; intermediate for defatted germ, soya and lupins, and lowest for cotton and copra. Data was also tested to determine whether N degradation constants could be predicted from DM loss constants. The correlations for the corresponding constants were 0.82 $(\mathrm{P}=0.014), 0.78(\mathrm{P}=0.022)$, and $0.91(\mathrm{P}=0.002)$ for the soluble fraction, slowly degradable fraction and the rate of degradation respectively.

Table 2 The true protein digestibility in cockerels, the effective degradability of protein and the digestible ruminal undegradable protein of plant protein supplements

\begin{tabular}{lccccrrrr}
\hline & \multicolumn{3}{c}{ Effective N Loss $(\mathrm{g} / \mathrm{kg})$ in } & \multicolumn{2}{c}{ Digestion in } & & \multicolumn{3}{c}{ Digestible UDP $(\mathrm{g} / \mathrm{kg} \mathrm{N})$} \\
\cline { 2 - 4 } Source & Sheep & Beef & Dairy & Chicken; $\mathrm{g} / \mathrm{kg}$ & Sheep & Beef & Dairy \\
\hline Canola & 780.74 & 712.11 & 648.50 & 870.0 & 89.26 & 157.89 & 221.50 \\
Copra & 678.85 & 599.72 & 534.05 & 782.0 & 103.15 & 182.28 & 247.95 \\
Cotton & 774.47 & 708.80 & 644.54 & 858.0 & 83.53 & 149.20 & 213.46 \\
Defatted germ & 741.48 & 671.25 & 605.71 & 855.0 & 113.52 & 183.75 & 249.29 \\
Lucerne & 786.51 & 712.33 & 643.28 & 815.0 & 28.49 & 102.67 & 171.72 \\
Lupins & 844.49 & 793.73 & 731.62 & 932.0 & & 87.51 & 138.27 & 200.38 \\
Soya & 774.45 & 691.71 & 619.22 & 873.0 & & 98.55 & 181.29 & 253.78 \\
Sunflower & 787.04 & 706.47 & 634.71 & 914.0 & 126.96 & 207.53 & 279.29 \\
\hline
\end{tabular}

The effective degradabilities were high and so was the digestibility of true protein in the cockerels for all protein supplements (Table 2). The effective degradabilities differed considerably between ruminant species. The correlation between the effective DM loss and the effective $\mathrm{N}$ loss was poor $(\mathrm{r}=0.51 ; \mathrm{P}=0.19)$. Digestible undegradable protein (UDP) was calculated as the difference between the digestibility of true protein (in cockerels) and the effective degradability of protein in the rumen. The data indicates that whilst most plant proteins are largely rumen degradable in sheep (and thus contain $0-9.9 \%$ of protein as digestible UDP), most supply moderate levels of digestible UDP (8.9-22.2\%) when fed to dairy cattle. Recent protein evaluation systems require the partitioning of feed protein into a ruminally degradable fraction and digestible undegradable protein (Beever, 1996; Tamminga et al., 1994). This study has demonstrated that most plant proteins are predominantly degradable in ruminants, though could supply appreciable quantities of digestible UDP in dairy cattle. In order to estimate the effective degradability, the approach was to subject the soluble portion to both degradation and passage, which theoretically should be valid given that this portion undergoes both processes simultaneously. The applicability of the digestibility of true protein determined (in cockerels) is questionable in view of the fact that microbial digestion of fibre could render otherwise encapsulated protein available for digestion. This could explain why lucerne had a negative digestible UDP. It is however important to note that the digestibility of true protein was correlated with the effective degradability of protein in the rumen $(\mathrm{r}=0.75, \mathrm{P}=0.03)$. Given the very high digestibilities of true protein, it might well be that in the absence of properly prepared animals for the implementation of the mobile bag technique (Hveplund, 1985) acceptable estimates could be obtained using cockerels.

\section{Conclusion}

It is concluded that the digestible UDP component of feed protein varies among feeds and among animals, being highest in dairy cattle.

\section{References}

AOAC, 1984. Official methods of analysis. $15^{\text {th }}$ ed. Washington, DC. pp 69-88.

Beever, D.E., 1996. S. Afr. J. Anim. Sci. 26, 20.

Hvelplund, T., 1985. Acta Agric. Scand. Suppl. 25, 132.

Mehrez, A.Z. \& Ørskov, E.R., 1977. J. agric. Sci., Camb. 88, 645.

Ørskov, E.R. \& McDonald, I., 1979. J. agric. Sci., Camb. 92, 499.

Tamminga, S. et al., 1994. Livest. Prod. Sci. 40, 139. 